\title{
実測デー夕に基づく木造住宅の三次元非線形動的挙動解析モデルの構築 CONSTRUCTION OF THREE-DIMENSIONAL NONLINEAR DYNAMIC MODELS FOR WOODEN STRUCTURES BASED ON ACTUAL MEASUREMENTS AND EXPERIMENTS
}

\author{
田中宏明*, 川瀬＼cjkstart博** \\ Hiroaki TANAKA and Hiroshi KAWASE
}

\begin{abstract}
In this paper, first we measure microtremors of wooden structures to obtain their natural frequencies. Then we construct three-dimensional structure models based on experiment data, such as beam-column connections, brace-column connections, shear walls with brace and panels, and so on. Next, we compare natural frequencies from microtremors with those acquired from eigenvalue analyses of three-dimensional structure models. We construct inverted elastic models by increasing stiffness until the natural frequency matches with the observed one. Then we examine whether the models are appropriate by comparing its nonlinear behavior with the result of a full-scale shaking table test of a wooden structure. Finally we evaluate the seismic performance of the wooden structures by using earthquake observation records and simulated strong ground motions. We confirmed that the natural periods of wooden structures obtained from microtremor linearly correlate with their wall-length ratios. We also confirmed that dynamic characteristics of structure models could be tuned up to approximate those of mirotremors. Finally we confirmed that modern wooden structures that we studies here seem to have sufficient seismic performance so that they would not be collapsed or heavily damaged for strong ground motions in the near-fault regions.
\end{abstract}

Keywords : microtremor measurement, natural frequency, wooden house, dynamic characteristics, seismic performance 常時微動計測, 固有振動数, 木造住宅, 振動特性, 耐震性能

\section{1. はじめに}

兵庫県南部地震では多くの木造住宅が全壊または半壊し、そのこ とが直接の原因になって多くの人命が失われたことは周知のことで ある。今後の地震被害軽減のために強震動予測とともに木造住宅に 関して、より現実的な地震時挙動解析モデルの構築が不可欠である。 兵庫県南部地震以降木造住宅に関しては実験や調査、観測など多 くの研究が精力的に行われてきた。しかし実験においては木質部材 や各接合部、耐力壁レベルでの実験が主であり、さらに壁倍率評価 など設計領域への適用を目指したものが多い。一部木造住宅の耐力 を把握することを目的とした実大実験なども行なわれているが木造 住宅の仕様の多さや間取りの多さを考えると十分なデータを与えて いるとは言えない。また調查研究においては、而震診断による木造 住宅の統計的調查や常時微動計測による振動特性把握に関する研究 もかなり行なわれているが、それらの結果を木造の耐震安全性評価 や挙動解析モデルと結びつけた研究はほとんどない。

地域防災を考える場合には、兵庫県南部地震以降指摘されている ように住民個々の危機意識の向上が極めて重要であるが、既往の行 政によるアンケート1)にもあるように、住民の住宅に関する危機意 識は一向に向上していないのが現状である。その理由として一番に
考えられるのは耐震性能が目に見える形で定量的に揭示できていな いことであり、地震による被害予測結果などが発表されてもリアリ ティがないというのが正直なところであろう。

以上のことから本研究では、まず寒木造住宅を対象とした常時微 動計測を実施してその固有振動数を把握し、その固有振動数と対象 とする住宅の図面などから、あらかじめ笳かいなどの部分実験デー タを基礎として構筑した柱梁フレームモデルを用いて、それを立体 的に構成することにより、実測データに基づいたリアリティのある 3 次元動的非線形挙動解析モデルを構築することを目的とする。そ してその挙動解析モデルを用いた強震動シミュレーションを行い、 実木造住宅の耐震性に関する考察を行う。

\section{2. 常時微動計測による木造住宅の振動特性把握}

\section{1 概要}

常時微動計測は比較的簡易に構造物の振動特性を把握する手段と して近年多くの計測が行なわれており、木造住宅でもいくつかの地 域で行なわれている例えば 2) 6)。何よりも常時微動計測は現時点での 対象建物の振動特性を把握できることにその意味がある。本項では 福岡市内を中心とした常時微動計測を行うことによって、まず木造
* 国土交通省近畿地方整備局 技官・修士(工学)

** 九州大学大学院人間環境学研究院 教授・工博
Engineer, MLIT, Kinki Regional Development Bureau, M. Eng. Prof., Faculty of Human-Environment Studies, Kyushu Univ., Dr. Eng. 
住宅の基本的性質としての振動特性を把握する。

\section{2 対象住宅および計測方法}

調查の対象は福岡県福岡市 31 棟と福岡県大牟田市 1 棟の計 32 棟 である。うち在来軸組木造が 31 棟、ツーバイフォー住宅が 1 棟と なっている。それら住宅の概要を表 1 に示す。計測機器は 0.1 倍か ら 10,000 倍のアンプつきのアカシ製 3 成分加速度計 SMA-R6A3P を用い、ハイカットフィルター周波数を $50 \mathrm{~Hz}$ 、サンプリング周波 数を $100 \mathrm{~Hz}$ とし 15 分間 (900 秒) 計測した。

加速度計の設置位置は 2 階床と地盤の 2 点である。それぞれ得ら れた加速度データを FFT 解析し地盤面に対する 2 階床における ーリエスペクトルの比から固有振動数を読み取った。なお木造住宅 の休面は RC 造建物などと同じレベルで剛であるとは言えず、分割 振動の可能性も考えられるため、予め表 1 中 Ta 邸に対して天井裏 1 台、2 階床に 5 台、1 階床に 1 台および地盤に 1 台加速度計を設置 して同時に常時微動計測を行い、地盤面に対する天井裏および地盤 面に対する 2 階床の固有振動数算定結果がほぼ同じであることを確 認している。

表 1 調査対象住宅の概要

\begin{tabular}{|c|c|c|c|c|c|c|}
\hline \multirow{2}{*}{ 略称 } & \multirow{2}{*}{ 建築年 } & \multirow{2}{*}{$\frac{\text { 床面積 }\left(\mathrm{m}^{2}\right)}{1 \mathrm{~F} / 2 \mathrm{~F}}$} & \multirow{2}{*}{ 屋根 } & \multirow{2}{*}{$\begin{array}{l}\text { 構造 } \\
\text { 形式 }\end{array}$} & \multicolumn{2}{|c|}{ 壁率 $\left(\mathrm{cm} \cdot / \mathrm{m}^{2}\right)$} \\
\hline & & & & & 药間 $1 \bar{F} / 2 \mathrm{~F}$ & 标行 $1 F / 2 F$ \\
\hline $\mathrm{Ta}$ & 1984 & $65.41 / 22.77$ & 重 & 軸組 & $50.08 / 93.92$ & $43.12 / 43.96$ \\
\hline Ks & 1998 & $121.57 / 86.53$ & 軽 & 軸組 & $48.81 / 40.62$ & $49.67 / 35.48$ \\
\hline $\mathrm{Hk}$ & 1997 & $138.41 / 76.66$ & 重 & 軸組 & $49.04 / 33.19$ & $47.29 / 29.64$ \\
\hline Mo & 2000 & $139.00 / 87.74$ & 重 & 軸組 & $52.53 / 31.58$ & $50.76 / 32.62$ \\
\hline$\overline{\mathrm{MN}}$ & 2002 & $149.88 / 94.53$ & 重 & 軸組 $\%$ & $50.83 / 64.03$ & $56.61 / 37.90$ \\
\hline$E$ & 2001 & $108.06 / 87.77$ & 重 & 軸組 & $64.21 / 77.76$ & $52.21 / 45.62$ \\
\hline $\mathrm{Ha}$ & 1995 & $77.32 / 54.54$ & 軽 & パネル & $66.92 / 61.99$ & $47.96 / 73.67$ \\
\hline IR & 1987 & $87.06 / 76.18$ & 重 & 軸組 & $62.44 / 53.75$ & $63.01 / 73.67$ \\
\hline $\mathrm{A}$ & 1979 & $98.33 / 26.49$ & 重 & 軸組 & $37.02 / 61.83$ & $39.33 / 85.88$ \\
\hline $\mathrm{KU}$ & 1995 & $60.00 / 60.00$ & 軽 & 軸組 & - & - \\
\hline TK & 1985 & $84.10 / 37.16$ & 重 & 軸組 & $\overline{-}$ & - \\
\hline MT & 1986 & $52.00 / 48.00$ & 軽 & 軸組 & - & - \\
\hline $\mathrm{Ho}$ & 1981 & $91.66 / 28.27$ & 重 & 軸組 & $42.56 / 61.51$ & $41.28 / 38.24$ \\
\hline $\mathrm{Ma}$ & 1991 & $95.90 / 36.88$ & 重 & 軸組 & $52.48 / 65.39$ & $54.56 / 63.11$ \\
\hline $\mathrm{Sa}$ & 1983 & $86.95 / 28.98$ & 重 & 軸組 & $42.39 / 78.50$ & $38.20 / 43.96$ \\
\hline Ko & 1994 & $64.59 / 51.34$ & 軽 & 軸組 & $75.73 / 73.56$ & $50.72 / 45.20$ \\
\hline I & 1998 & $89.73 / 56.31$ & 軽 & 軸組 & $54.36 / 85.53$ & $63.89 / 45.25$ \\
\hline $\mathrm{Na}$ & 1993 & $64.53 / 50.54$ & 軽 & 軸組 & $86.49 / 66.73$ & $61.93 / 41.82$ \\
\hline Sh & 1981 & $67.90 / 33.95$ & 重 & 軸組 & $56.29 / 62.99$ & $45.56 / 85.77$ \\
\hline $\mathrm{Hi}$ & 1981 & $55.48 / 43.06$ & 軽 & 軸組 & - & - \\
\hline IS & 1980 & $70.39 / 26.50$ & 重 & 軸組 & $47.19 / 54.94$ & $53.97 / 63.53$ \\
\hline SY & 1979 & $78.26 / 46.37$ & 重 & 軸組 & $42.84 / 53.21$ & $38.72 / 81.67$ \\
\hline NS & 1979 & $69.56 / 26.50$ & 重 & 軸組 & $55.60 / 51.51$ & $37.28 / 87.57$ \\
\hline $\mathrm{Ka}$ & 1980 & $67.90 / 26.50$ & 重 & 軸組 & $56.29 / 44.64$ & $40.21 / 99.70$ \\
\hline IW & 1980 & $71.22 / 26.50$ & 軽 & $\begin{array}{c}\text { 軸組 } \\
\end{array}$ & $58.46 / 44.64$ & $44.08 / 99.58$ \\
\hline MR & 1979 & $73.70 / 33.12$ & 重 & 軸組 & $51.37 / 43.96$ & $48.07 / 55.64$ \\
\hline $\mathrm{KN}$ & 1980 & - & 重 & 軸組 & - & - \\
\hline IK & 1970 & - & 重 & 軸組 & - & - \\
\hline$T M$ & 1973 & - & 重 & 軸組 & - & - \\
\hline IK & 1974 & - & 重 & 軸組 & - & - \\
\hline ST & 1960 & - & 重 & 軸組 & $\overline{-}$ & - \\
\hline Wa & 1981 & - & 軽 & 軸組 & $\overline{-}$ & - \\
\hline
\end{tabular}

※一部パネルを含む

注：図中ーは調査でデータが得られなかった部分である

\section{3 計測結果}

図 1 にフーリエスペクトル比の代表例として表 1 中の $\mathrm{Ta}$ 邸およ び Ho 邸の張間方向および桁行方向それぞれのフーリエスペクトル 比を示す。また表 2 に常時微動計測結果より得られた各住宅の固有 振動数を示す。図 2 には建築年に対する 1 次固有振動数との関倸を 示す。また図 3 には各住宅の壁率より算出した $1 、 2$ 階の平均充足 率(充足率=存在壁量/必要壁量)に対する固有振動数の関倸を示す。
表 2 から分かるように今回の対象住宅の平均 1 次固有振動数は $6.58 \mathrm{~Hz}$ となっており木造住宅は微小振動時には大変硬いと言える。 これらの結果は既往の調查侧え活 2) 6) と比較してもおおよそ同様の結 果となっている。図 2 より建築年代と固有振動数との関係は年代が 新しくなる（筑年数が短くなる）と固有振動数が高くなる傾向が見 られるが、1980 年代以降はその傾向は小さくばらつきが大きい。近 年の木造住宅は固有振動数への影響柱築年数だけでは説明できない。
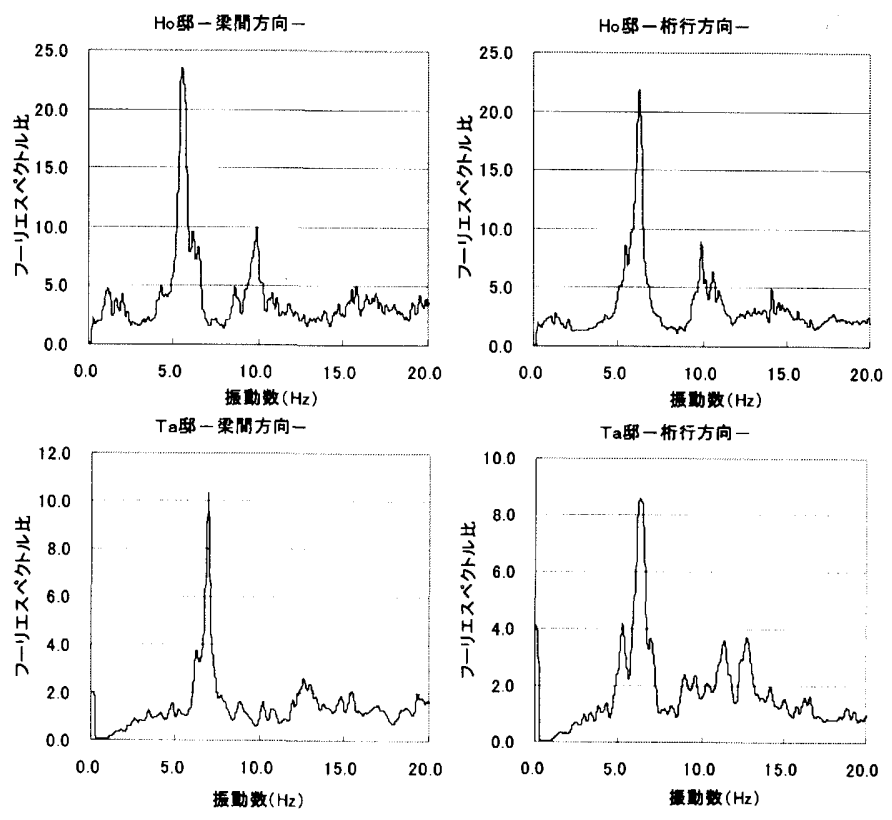

図 1 フーリエスペクトル比の例

表 2 常時微動計測より得られた固有振動数

\begin{tabular}{|c|c|c|c|c|c|}
\hline 略称 & 建築年 & \begin{tabular}{|l|} 
1次直有 \\
梁間方向 \\
\end{tabular} & 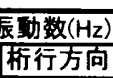 & $\begin{array}{l}\text { 次固有 } \\
\text { 梁間方向 }\end{array}$ & $\begin{array}{l}\text { 動数( }(\mathrm{Hz}) \\
\text { 行行方向 }\end{array}$ \\
\hline $\mathrm{Ta}$ & 1984 & 6.86 & $\begin{array}{l}6.15 \\
\end{array}$ & 13.62 & 12.72 \\
\hline Ks & 1998 & 8.11 & 7.87 & 18.02 & 16.48 \\
\hline $\mathrm{Hk}$ & 1997 & 6.54 & 5.98 & 15.63 & 14.92 \\
\hline Mo & 2000 & 7.01 & 6.27 & 16.75 & 15.26 \\
\hline$\overline{M N}$ & 2002 & 7.74 & 6.84 & 16.50 & 14.38 \\
\hline$E$ & 2001 & 5.69 & 5.25 & 14.99 & 12.43 \\
\hline $\mathrm{Ha}$ & 1995 & 9.38 & 8.25 & 19.70 & 19.09 \\
\hline IR & 1987 & 6.23 & 6.27 & 12.45 & 15.48 \\
\hline A & 1979 & 5.25 & 7.59 & 17.97 & 18.87 \\
\hline $\mathrm{KU}$ & 1995 & 6.01 & 5.77 & 14.50 & 14.70 \\
\hline TK & 1985 & 7.20 & 7.20 & 13.84 & 16.60 \\
\hline MT & 1986 & 6.37 & 5.35 & 14.79 & 15.60 \\
\hline $\mathrm{Ho}$ & 1981 & 5.64 & 6.17 & 9.91 & 10.64 \\
\hline $\mathrm{Ma}$ & 1991 & 6.18 & 6.84 & 15.26 & 12.62 \\
\hline $\mathrm{Sa}$ & 1983 & 6.27 & 5.23 & 12.40 & 9.77 \\
\hline Ko & 1994 & 6.69 & 6.84 & 15.14 & 17.48 \\
\hline I & 1998 & 7.13 & 6.57 & 15.97 & 13.54 \\
\hline $\mathrm{Na}$ & 1993 & 6.69 & 6.45 & 16.43 & 16.43 \\
\hline Sh & 1981 & 6.74 & 7.64 & 12.96 & 14.45 \\
\hline $\mathrm{Hi}$ & 1981 & 7.74 & 8.69 & 16.16 & 19.87 \\
\hline IS & 1980 & 6.15 & 7.84 & 12.04 & 17.68 \\
\hline$S Y$ & 1979 & 5.76 & 6.47 & 12.13 & 13.48 \\
\hline NS & 1979 & 6.30 & 7.67 & 12.13 & 14.99 \\
\hline $\mathrm{Ka}$ & 1980 & 7.10 & 6.23 & 14.50 & 12.84 \\
\hline IW & 1980 & 7.67 & 8.89 & 14.45 & 18.87 \\
\hline MR & 1979 & 6.93 & 6.64 & 13.87 & 14.79 \\
\hline $\mathrm{KN}$ & 1980 & 5.88 & 6.71 & 11.43 & 15.99 \\
\hline IK & 1970 & 4.47 & 4.47 & 9.64 & 12.57 \\
\hline TM & 1973 & 5.08 & 6.25 & 13.82 & 14.65 \\
\hline IK & 1974 & 4.42 & 5.03 & 12.33 & 14.45 \\
\hline ST & 1960 & 4.79 & 4.27 & 10.55 & 11.21 \\
\hline Wa & 1981 & 8.01 & 9.35 & 18.73 & 18.48 \\
\hline
\end{tabular}




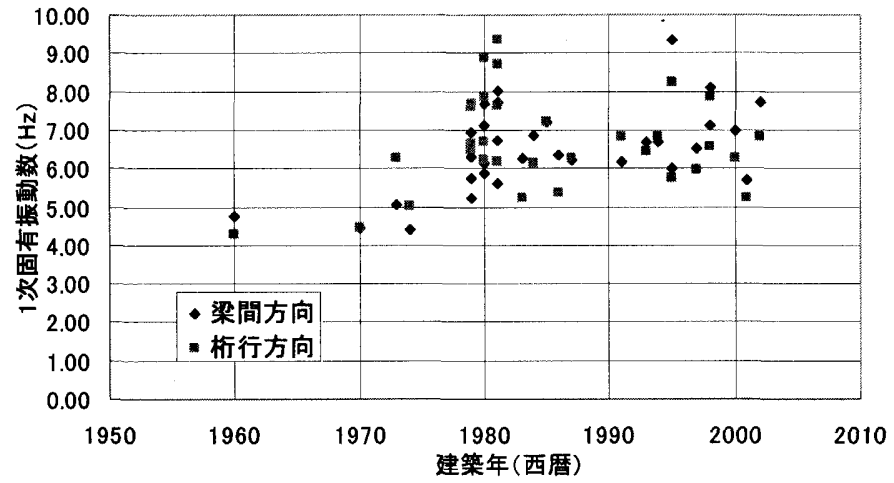

図 2 固有振動数と建築年との関係

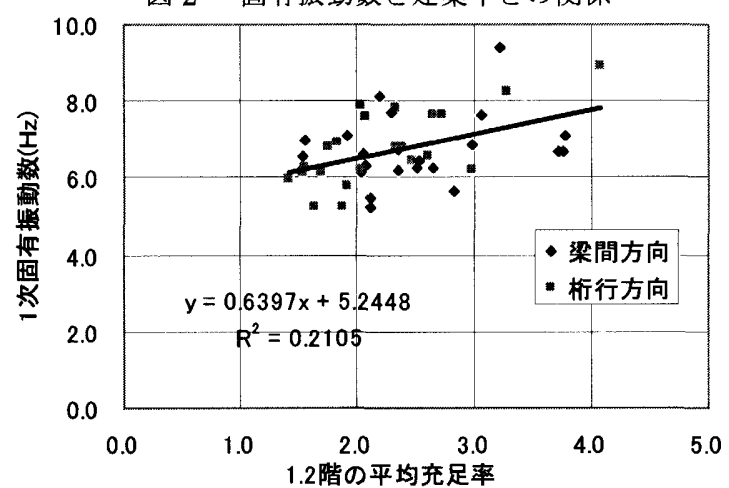

図 3 固有振動数と 1,2 階の平均充足率との関倸

図 3 より固有振動数と充足率にはばらつきが大きいが一定の相関が あることがわかる。図 3 中には表 1 で分かるように 1980 年代以降 のものが多くプロットされており、近年の木造住宅の振動特性は壁 量により規定されていると言える。ばらつきの原因には微小振動時 にはいわゆる構造体である耐力壁以外にも垂壁や腰壁、その他の雑 壁の寄与が大きいことや、充足率を算出する場合の必要壁量が床面 積によって決定されており、各住宅の重量の違いを十分に反映でき ていないことも理由として考えられる(なお屋根の軽重は基準法に 基づいて考虑されている)。ばらつきは大きいながらも、縦軸の常時 微動計測より得られた固有振動数と横軸の図面より得られた充足率 の間に一定の相関があることから、建物の上下 2 台の加速度計を用 いて常時微動計測を行い、固有振動数を把握することで、充足率で 代表される木造住宅の相対的な耐震性が推定可能であると言える。

\section{3 次元挙動解析モデルの構築}

\section{1 構筑手法}

木造の軸組は木材自身とそれぞれの部材をつなぐ接合部によって 構成される。そもそも部材自身の変形性能は小さく軸組構造の変形 性能の多くは接合部が受け持っていると言ってよい7)。そこで 3 次 元構造モデルを構築するにあたり最小単位として部材接合部を考慮 できるモデルを構筑することとする。また木造住宅はその水平抵抗 能力を壁率で規定されていることから、モデル化に際して耐力壁を 基準として考えることとする。つまり構造物の挙動解析モデルを構 築する方法としてまず耐力壁レベルでのモデルを構築し、その後そ のモデルを用いて構造物レベルに拡張する。

\section{2 耐力壁モデル}

耐力壁は大きく管かい耐力壁と面材耐力壁に分けられる。そこで それぞれの耐力壁を図 4 に示すように筋かい耐力壁は部材および軸
方向バネ、回転方向バネでモデル化し、面材耐力壁は置換ブレース によってモデル化する。それぞれの復元力特性およびその特性值(図 4 中 G1,G2,D1,D2 など)は既往の部分実験 ${ }^{8)}$ 19)をもとに、既往の水 平加力実験 20) 31) から得られる变位荷重曲線を一般的に再現できる ように決定した。これらを初期モデルと呼ぶことにする。
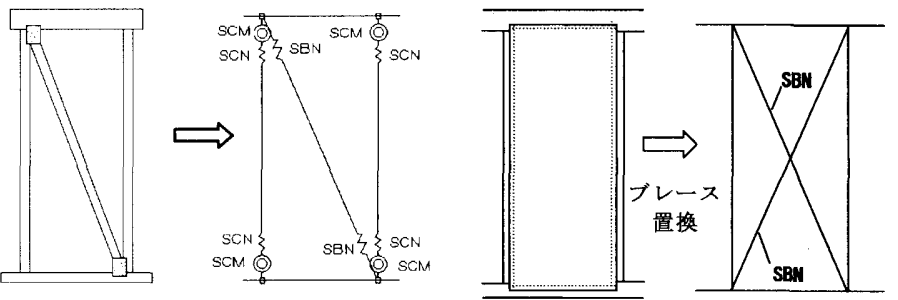

$\mathrm{SCN}$ ：筇かい耐力壁の柱一横架材接合部軸方向バネ

SBN : 筋かい耐力壁の柱・横架材接合部一筋か、接合部軸方向バネ SCM：筋かい耐力壁の柱一横架材接合部回転方向バネ SBN：置換ブレース
（a）筋加以耐力壁
（b）面材耐力壁
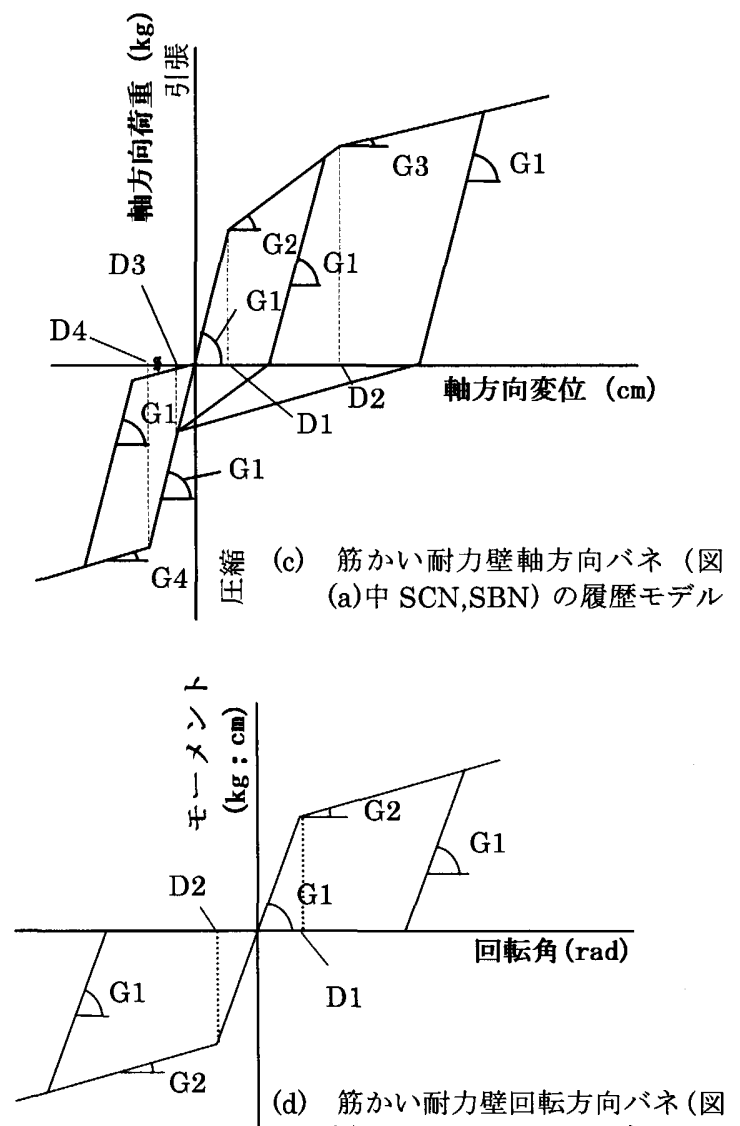
(a)中 SCM）の履歴モデル

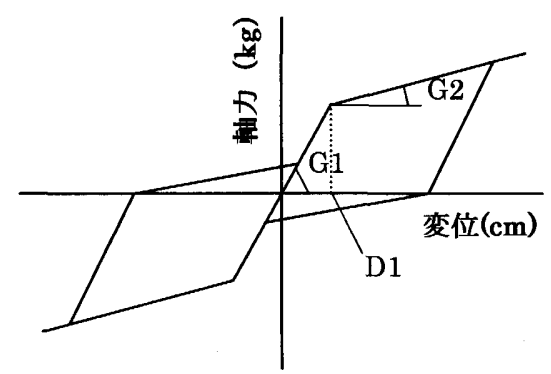

（e）面材耐力壁置換ブレース（図(b)中SBN）の履歴モデル 図 4 耐力壁モデルの構築手法 


\begin{tabular}{|l|r|r|r|r|r|r|r|r|}
\hline & G1 & G2 & G3 & G4 & D1 & D2 & D3 & D4 \\
\hline SCN & 10500 & 2300 & 450 & 800 & 0.03 & 0.21 & 0.018 & 0.2 \\
\hline SBN & 7580 & 1320 & 310 & 2270 & & & & \\
\hline SCM & 258000 & 19500 & & & 0.0083 & & & \\
\hline SBM(石膏ボード) & 1300 & 300 & & & 0.15 & & & \\
\hline SBM(モルタル外壁 & 1800 & 100 & & & 0.2 & & & \\
\hline
\end{tabular}

単位 $\mathrm{G} 1 \sim \mathrm{G} 4: \mathrm{kg} / \mathrm{cm}$ (ただし $\mathrm{SCM}$ は $\mathrm{kg} \cdot \mathrm{cm} / \mathrm{rad}$ ) D1〜D4：cm（ただし SCMは $\mathrm{rad）}$

(f) 各履歴モデルの特性值

図 4 耐力壁モデルの構築手法（つづき）

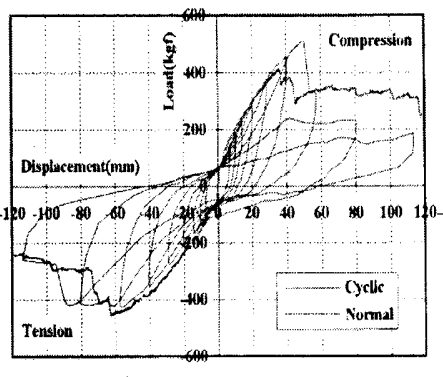

実験結果（文献 23）より）

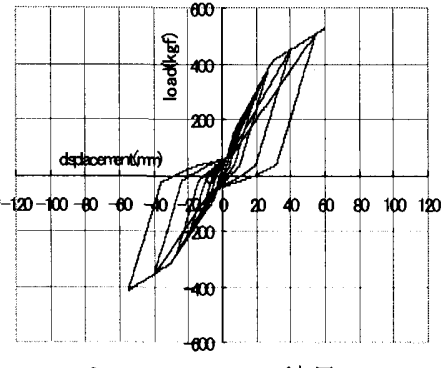

シミュレーション結果 （a）筋かい耐力壁

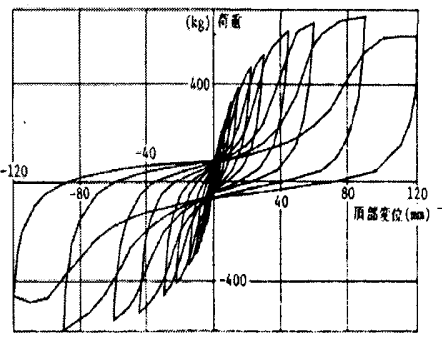

実験結果（文献 31）より)

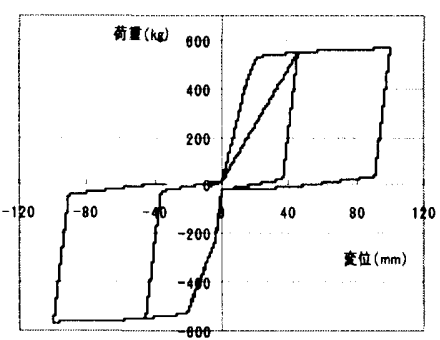

シミュレーション結果 (b) 面材耐力壁

図 5 耐力壁の水平加力実験結果とシミュレーション結果

図 5 には図 4 に示した耐力壁のモデル化から得られたシミュレー ションの結果を、対象とする耐力壁の実験結果とともに例示する。

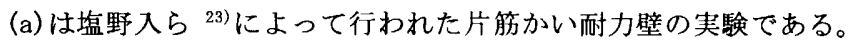
(b) は大橋ら ${ }^{30) 311}$ によって行われたラスモルタル外壁の実験結果で ある。(b) は外壁の長さが $2 \mathrm{P}(1820 \mathrm{~mm})$ で高さが $2730 \mathrm{~mm}$ の物を想定し ている。(実際の試験体は長さ $1200 \mathrm{~mm}$ 、高さ $1887 \mathrm{~mm}$ )。図から図 4 に示すようなモデル化によって既往の実験結果をおおむね再現する ことができた。

\subsection{3 次元構造物モデル}

図 4 の耐力壁モデルを用いて構造物レベルに拡張する。3 次元構 造モデルへの拡張は常時微動計測時に入手した住宅の図面を基本に 構筑した。図 6 にはその例として Ta 邸の図面を図 7 にはそれをもと に組み上げた 3 次元構造モデルを示す。今回は調査を行った 32 棟中、 より詳細な図面を入手することができた計 9 棟 (図 7 に示す Ta 邸を 含む)について 3 次元構造モデルの構築を行っている(付録参照)。な お、床パネルの剛性は考慮せず梁の面外曲げ剛性のみ評価している。

3 次元構造モデルと微動による実在住宅の固有振動数を比較する ため、それぞれ図面をもとに 3 次元の構造モデルを組み上げ、その モデルに対して得られる固有振動数を、常時微動計測結果から得ら れた実際の固有振動数と比較すると常時微動による固有振動数が高 く、構造モデルの剛性がかなり不足することが分かった。そこで初
期モデルの初期剛性を増加させ、どの程度剛性を增加させると常時 微動計測結果に近似できるかを試みたところ各住宅の平均で 6.3 倍 と大きな值となった。表 3 には各住宅の剛性倍率（初期モデルの剛 性に対する比）を示す。そもそも初期モデル構築の際のフレーム初 期剛性は水平加力実験結果に合うように構築しており、初期モデル の初期剛性の理論的根拠が多少あいまいなので、この数字をそのま ま考察することは難しいが、一般的に微小振動時には雑壁や仕上げ などの影響が非常に大きいことが予想されるので、この数字もその 影響が大であることを示しているものと考えられる。図 8 は縌軸に 微動結果、横軸に固有值解析結果をプロットしたものである。この 図から、図面から組み上げた構造モデルの剛性を增加させて実在住 宅の固有振動数に合うようにフィッティングできていることがわか る。しかし 2 次固有振動数では常時微動計測結果より得られる固有 振動数が多少高くなっており、この原因はモデルの 1 階と 2 階の剛 性比及び質量比の精度が不足しているのではないかと推察される。

さて木造住宅のモデル化を行う際に注意すべきは、そもそも木造 住宅は非常に早い段階から非線形化するため微小振動時における剛 性をそのままモデルに考慮することは現実的でないということであ る。そこで常時微動計測結果を挙動解析モデル構筑に生かすため既 往の実大振動台実験時の常時微動計測とスイープ武験 (加速度レベ ルで 100〜150gal に相当)それぞれから得られた固有振動数の関倸 (図 ${ }^{32)}$ )を用いて換算した固有振動数に合うように剛性を調整し

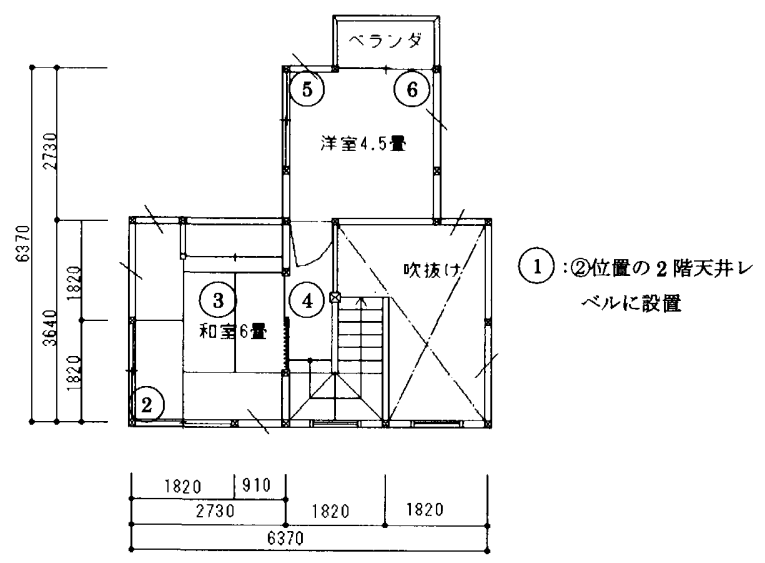

(a) 2 階平面図
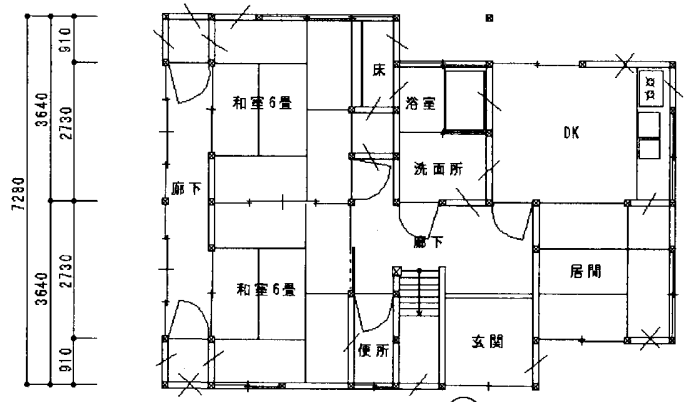

(a)

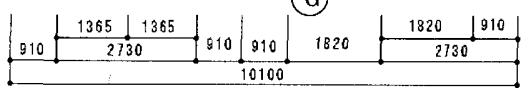

(b) 1 階平面図

図 $6 \mathrm{Ta}$ 邸の平面図 


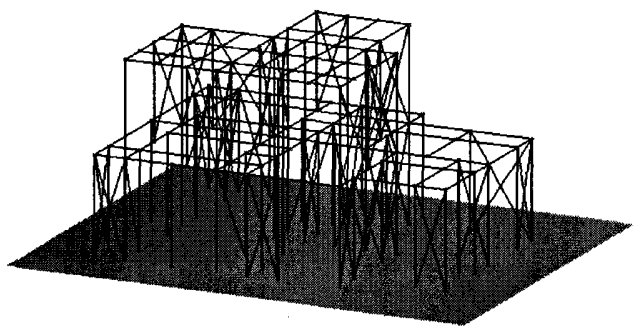

図 7 Ta 邸の構造物解析モデル

表 3 構造モデルと実在住宅の固有振動数の比較

\begin{tabular}{|c|c|c|c|c|c|c|c|c|c|c|}
\hline \multirow{3}{*}{ No. } & & \multicolumn{4}{|c|}{ 椎造モデルの固有振動数 $(\mathrm{Hz})$} & \multicolumn{4}{|c|}{ 英在住宅の固有振動数 $(\mathrm{Hz})$} & \multirow{3}{*}{ 倍乖 } \\
\hline & & \multicolumn{2}{|c|}{ 1次 } & \multicolumn{2}{|c|}{ 2次 } & \multicolumn{2}{|c|}{ 1次 } & \multicolumn{2}{|c|}{ 2次 } & \\
\hline & & 染間 & 标行 & 粱間 & 析行 & 粱間 & 析行 & 粱間 & 标行 & \\
\hline & $\mathrm{Ta}$ & 7.17 & 5.93 & 13.74 & 11.75 & 6.86 & 6.15 & 12.79 & 13.62 & 6.2 \\
\hline & & 5.72 & 6.84 & 11.51 & 14.31 & 6.23 & 6.27 & 12.45 & 15.48 & 1.2 \\
\hline 3 & Ho & 5.59 & 6.06 & 8.97 & 11.09 & 6.17 & 5.64 & 10.64 & 9.91 & 5.6 \\
\hline 14 & $\mathrm{Ma}$ & 6.01 & 7.07 & 11.15 & 11.42 & 6.18 & 6.84 & 15.26 & 12.62 & 6.5 \\
\hline 15 & Sa & 6.38 & 5.15 & 9.70 & 8.96 & 6.27 & 5.23 & 12.40 & 9.77 & 6.2 \\
\hline 16 & K & 7.12 & 6.54 & 13.28 & 12.55 & 6.69 & 6.84 & 15.14 & 17.48 & 5.4 \\
\hline 17 & & 6.92 & 6.76 & 17.51 & 11.83 & 7.13 & 6.57 & 15.97 & 13.54 & 5.9 \\
\hline 21 & Is & 6.60 & 7.15 & 11.66 & 14.06 & 6.15 & 7.84 & 12.04 & 15.60 & 6.3 \\
\hline 24 & $\overline{\mathrm{Ka}}$ & 6.69 & $\overline{6.53}$ & 12.52 & 13.28 & 7.10 & 6.23 & 14.50 & 12.84 & 7.1 \\
\hline
\end{tabular}

※注表中構造モデルの固有振動数とは、構造モデルの 1 次振動数 を実在住宅の固有振動数に近似させた後の值である

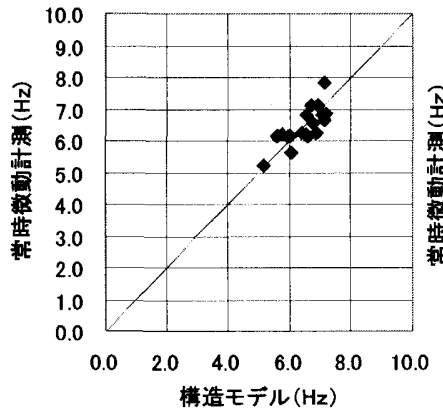

(a) 1 次固有振動数

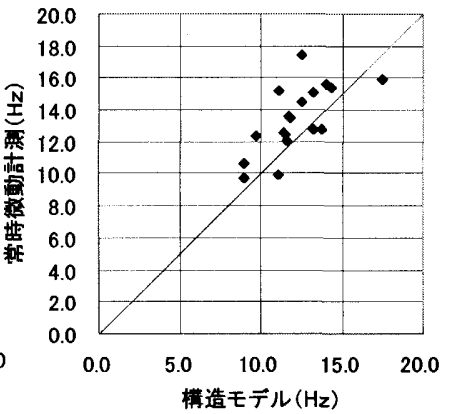

(b) 2 次固有振動数

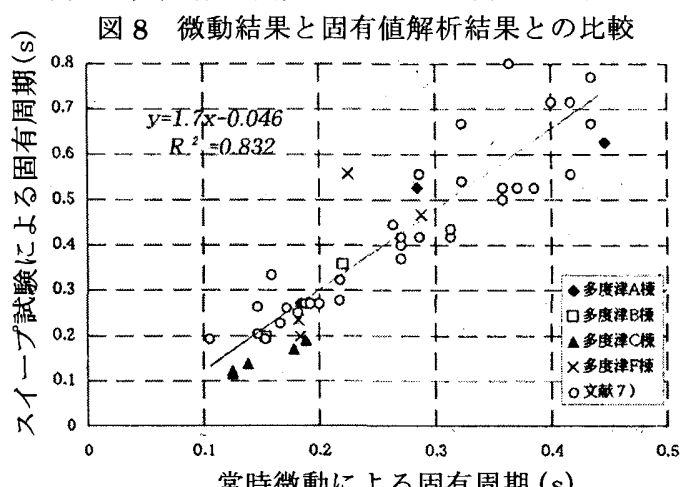

常時微動による固有周期 $(s)$

図 9 実大実験結果による固有周期の関倸 32)

た。ただし図 9 中の試験体（特に周期の長い部分）には完成体でな い物も含んでいるが、本研究では対象とする住宅の固有周期が短い ことから図 9 の回帰式を使用することとした。その結果得られた構 造モデルの固有振動数を図 9 の関係を用いて換算した固有振動数と ともに表 4 に示す(1 次振動数のみ)。表 4 より平均の剛性倍率は 3.0 倍となった。一般に雑壁 (非耐力壁) の水平力負担は $1 / 3$ と言われ ること ${ }^{33)}$ を考慮すると、この 3 倍という数值は依然としてかなり大

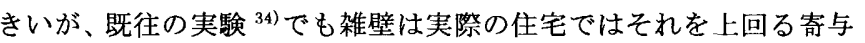
が考えられると指摘しておりそれらを考慮するとこの值は中程度の 摇れに対する妥当な数值であると考えられる。従ってモデルの初期
表 4 変換した固有振動数と同定した固有振動数

\begin{tabular}{|c|c|c|c|c|c|c|}
\hline \multirow{2}{*}{ No. } & \multirow{2}{*}{ 略称 } & \multicolumn{2}{|c|}{ 構造モデルの固有振動数 $\left(\mathrm{Hz}_{2}\right.$} & \multicolumn{2}{|c|}{ 实在住宅の固有振動数 $(\mathrm{Hz})$} & \multirow{2}{*}{ 倍率 } \\
\hline & & 梁間 & 析行 & 粱間 & 咑行 & \\
\hline 1 & $\mathrm{Ta}$ & 5.14 & 4.25 & 4.96 & 4.34 & 2.9 \\
\hline 8 & IR & 4.08 & 4.86 & 4.40 & 4.45 & 3.5 \\
\hline 13 & $\mathrm{Ho}$ & 3.95 & 4.29 & 4.36 & 3.92 & 2.7 \\
\hline 14 & $\mathrm{Ma}$ & 4.27 & 5.03 & 4.36 & 4.93 & 3.2 \\
\hline 15 & Sa & 4.43 & 3.58 & 4.45 & 3.58 & 2.9 \\
\hline 16 & Ko & 5.17 & 4.68 & 4.80 & 4.93 & 2.6 \\
\hline 17 & I & 4.98 & 4.88 & 5.20 & 4.70 & 3.0 \\
\hline 21 & Is & 4.79 & 5.16 & 4.34 & 5.85 & 3.2 \\
\hline 24 & $\mathrm{Ka}$ & 4.71 & 4.59 & 5.17 & 4.41 & 3.3 \\
\hline
\end{tabular}

剛性としては初期モデルに表 4 中に示す倍率を乗じた值を用いるこ ととする。

次に各接合バネ（軸方向バネ及び回転方向バネ）や置換ブレース の非線形領域のモデル構筑手法について述べる（線材（柱、梁、筋 かい部材）は線形とする)。初期剛性に関しては前述のような手法で 構筑するが、非線形領域においては初期剛性のように常時微動計測 結果などからモデルを構築することは不可能であり、非線形領域の モデルを直接拘束するデータがない。そこで初期モデルの非線形特 性を基に構築する。初期剛性を増加させた場合に、初期モデルの剛 性変化点の降伏変位を一定にするとバネの最大耐力は初期剛性の倍 率に比例して大きくなる。しかしそのように非線形特性を決定する と非線形領域においても剛性が非常に大きくなり最大耐力が既往の 部分実験などと比較して現実的でない值となってしまう。そこで初 期モデルの剛性変化点の降伏荷重レベルを一定として構筮すること とする。その概念を図 10 に示す。

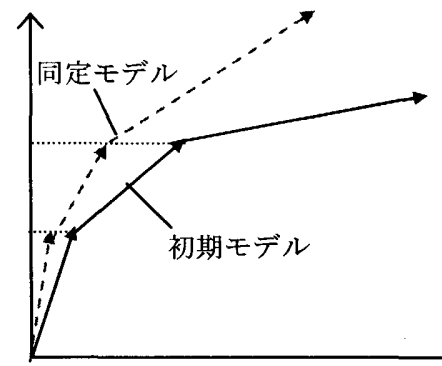

初期モデル : 3.2 項で構筑した モデル

同定モデル：表 4 中の初期剛 性倍率を乗じた 場合のモデル (イメージ)

図 10 接合バネや面材置換ブレースなどの非線形特性の構築手法

\section{4 挙動解析モデルと振動実験との比較}

前項のように初期モデルから常時微動計測結果に合うようにモデ ルを組み上げた挙動解析モデルが妥当であるかどうかを検証するた めに、原子力発電技術機構多度津工学試験所において実施された実 大木造住宅の振動台実験（図 $11(\mathrm{a}))^{36)}$ 37) と上記の方法で構筑した 構造モデル(図 $11(\mathrm{~b})$ ))の強震動シミュレーションとの結果を比較し た。それぞれの結果より得られた 1 層層せん断力ー層間変形角関係 を図 12 に示す。図より振動台実験結果に対して、シミュレーション 結果の忘答変位が幾分小さくなっている。実験の方は上下方向にも 地震波を入力しておりその結果接合部の変位が大きくなっているこ とも理由の一つとして考えられるが、そのほかに図 12 の履歴曲線か ら見て取れるように梏建築物特有であるスリップ性状が十分に再 現できていないこともその理由としてあげられ、接合バネや置換ブ レース（図 4) のモデルを再度検討する必要がある。なお図 11 に示 すように、この実験は付属物のないシンプルな構造に対して実施さ 
れており、実際の家屋の状況とは異なっている。

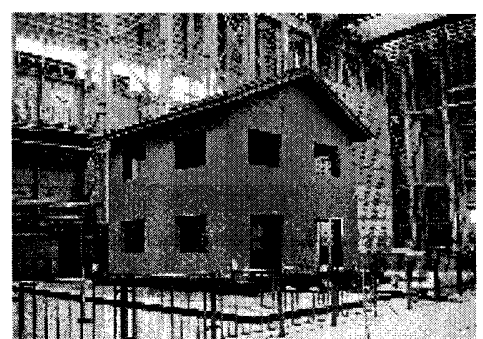

（a）振動実験供試体(文献 36 より)

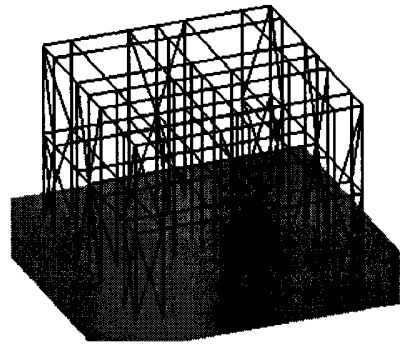

*質量に関して は各柱の支配面 積を考虑して、各 柱の頂部に集中 質量として加光 ている

(b) 解析モデル

図 11 実大木造住宅振動実験供試体と解析モデル

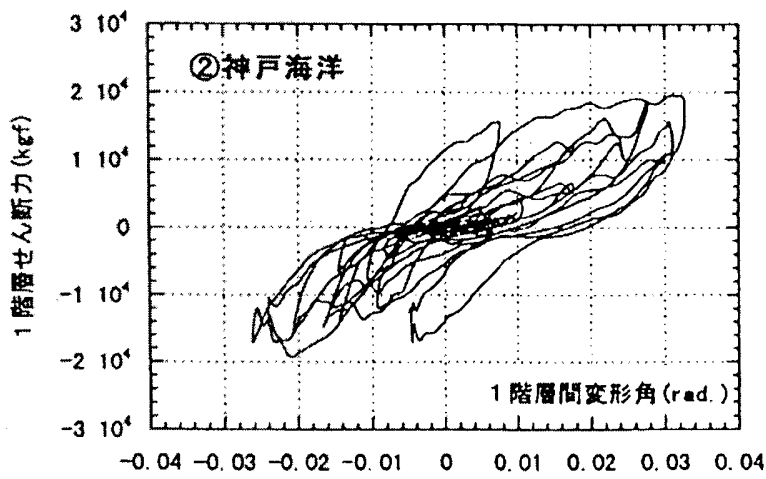

（a）実大振動台実験結果(文献 37)上り)

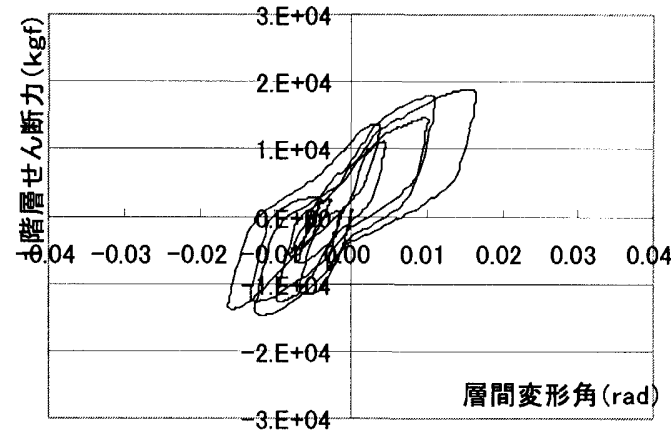

(b) 強震動シミュレーション結果

図 12 実大振動台実験との比較

\section{4. 強震動シミュレーション}

\section{1 概要}

表 3 に示す 9 棟に対して 3 章に示す方法で構築した 3 次元非線形 動的挙動解析モデル (Ta 邸以外は付録参照)を用いた強震動シミュ レーションを行い、これら木造住宅の耐震性能について考察を行う。

\section{2 入力地震動}

解析に用いる強震動は表 5 に示す兵庫県南部地震 (1995 年 1 月) 7
波 (松島・川瀬 ${ }^{38)}$ の再現波を含む)、鳥取県西部地震 (2000 年 10 月) 4 波、宮城県北部の地震 (2003 年 7 月) 4 波の計 15 波形とする ${ }^{38) ~ 41) 。 ~}$ 地震動は後述するように地震の違いによる構造物破壊能の違いを考 察するために、最大加速度が $200 \mathrm{Ga} 1$ 以上のものからそれぞれの地震 で記録されている最大の加速度を有するものの間において適宜に選 択した。入力は梁間方向、桁行方向の 2 方向同時入力とする。

\section{3 シミュレーション結果}

表 6 に解析モデル 9 棟に関するそれぞれ 15 波に対する 1 層最大 層間変位の一覧を示す(最大変位とは梁間、桁行 2 方向の変位を各時 刻でベクトル合成した内の最大の意味である。木造住宅の破壊は変 位で決まると仮定した場合に、方向ごとの変位でなく実変位を用い ることが妥当であると考えて合成変位を記載している)。表よりどの 住宅も最大応答変位は小さく被害が考えられる変位は生じなかった。 これは今回の調査対象住宅には十分な耐力があることを意味してお り、部材が破断したり接合部が引き拔けたりするようなことがない 限りこれまで観測された大きな強震動に対しても十分耐えうること が分かる。ただし図 12 のモデルと実大振動台結果との比較からも分 かるように、現時点でのモデルは実際の挙動に対して态答変位が小 さくなる可能性があるため注意が必要である。図 13 に态答変位波形 の代表として、Sa 邸に対して TTRH02 波を入力した際のシミュレー ションで、解析モデルの中で最大の态答変位を生じた部分の時刻歴 変位波形を示す(梁間方向)。図から最大变位を記録後応答変位は小 さくなり多少マイナス方向(図中下方向)への残留変位があるように 見えるが、その程度は小さく、この波形記録からも耐震性に問題は ないと考えられる。一方他の住宅に比べ Sa 邸の最大変位が全体的に 大きいことが表 6 から見て取れる。一般的に偏心率、直下率などが 応答に影響すると考えられるので、偏心率を各住宅について計算し た結果 0.15 を超えるものはほとんどなく文献 42)にあるように偏心 率が 0.15 以下では、偏心の応答への寄与は少ないといえる。また解 析対象住宅の直下率は小さい物から大きい物まで存在したが解析結 果と明膫な相関は見られなかった。このことを考慮すると応答が大 きくなった要因には、固有振動数が他の住宅に比べて小さいことで 入力地震動の卓越振動数に近くなったこと（特に非線形領域に入っ てさらに固有振動数が低くなること）が理由として考えられる。

最後に図 14 には地震ごとに分類した場合の 1 層最大層閒変位を 入力地震動の NS 成分 $\mathrm{EW}$ 成分の平均最大加速度に対して示す。この 図から兵庫県南部地震や鳥取県西部地震に比心゙宮城県北部の地震の 破壊能力が小さいことがわかる。また鳥取県西部地震では TTRH02 波や TTR008 波は強い破壊能力を有しているが他の地震波の破壊能 力は小さい。

\section{5. まとめ}

本研究では木造建物の実測データを用いた 3 次元非線形動的挙動 解析モデルを構築することを目的とし、まず福岡市内の比較的新し い木造住宅の常時微動計測を行った。その結果得られた固有振動数 と図面より算出した壁量から求めた充足率との間には一定の相関が あり、今回のように上下 2 台の加速度計を使用した常時微動計測か ら求められる固有振動数によって、木造住宅の第一次近似としての 相対的耐震性を抽出することが可能であることがわかった。 
次に 3 次元動的非線形挙動解析モデルを各部材や接合部、耐力壁 などの既往の蓄積されたデータをもとに構築し、そのモデルと上述 した常時微動計測より得られる実在住宅の振動特性に基づく動的挙 動解析モデルの構築を行い、既往の実大振動台実験との比較を行う ことによってその構築手法の妥当性を検証した。その結果本論で用 いたモデルの忘答は振動台実験結果より幾分小さくなっており、そ の要因として、実験では上下方向の地震入力を考慮していること、 モデリングでは、木造のスリップ性状が過小評価されている可能性、 静的モデルを動的なモデルへ適用する場合の違いなどが考えられる。 また本論におけるモデル構築法では、初期剛性に比例させる形で非 線形領域の剛性を決定しており、強震動に対する応答は非線形領域 に大きく左右されることを考えると、それが大変形時の応答を過小 評価する一因と考えられる。図 10 に示す剛性増大操作をしなかった 場合について、同様に図 11 のモデルを作成し、図 12 と同様の比較 を行った所、最大変形が 0.029rad と振動台実験結果とほぼ同じにな ったことから、今後さらに常時微動時と大変形時との剛性の関係な どを再考しモデル化手法の改良を行う必要があるといえる。

最後に対象とする木造住宅の耐震安全性を評価するため上述し た手法で 9 棟の建屋モデルを組み上げ、15 波の観測波および再現波 による強震動シミュレーションを行った。その結果次のような結論 を得た。(1)本論で解析の対象とした住宅は過去の強震動に対しても 十分な耐震安全性を有している。(2)常時微動計測によって得られた 固有振動数が大きいことは直接耐震安全性につながる要因である。 (3)宮城県北部の地震の加速度は大きいが構造物破壊能は小さい。

今後は部材レベル履歴モデルを大変形時の挙動をより良く再現 できるモデルへチューニングするとともに、構築したモデルの挙動 と実際の被害との整合性を統計的なレベルで対応を取ることにより、 大地震時における挙動を定量的に予測できるモデルとしたい。

\section{謝辞}

本研究では多くの赛験データおよび論文などを参考にさせて頂 きました。特に図の引用を快く許可いただきました笹川明、大橋好 光、宮沢健二の各先生方および日本住宅・木材技術センターには深 く感謝の意を表します。シミュレーションには K-NET・KiK-net・気 象庁のデータを使用しました。本研究の一部は文部科学省振興調整 費 (平成 $12 \sim 16$ 年度、代表者 入倉孝次郎)により実施されました。

表 5 入力地震動一覧

\begin{tabular}{|c|c|c|c|c|}
\hline \multirow{2}{*}{ 地震 } & \multirow{2}{*}{ No. } & \multirow{2}{*}{ 略称·呼称 } & \multicolumn{2}{|c|}{ 最大加速度 (gal) } \\
\hline & & & NS & $E W$ \\
\hline \multirow{3}{*}{ 兵庫県南部地震 } & 1 & JMAKOBE & 818.0 & 617.0 \\
\hline & 2 & 再現波345 & 830.7 & 284.5 \\
\hline & 3 & 再現波381 & 497.9 & 410.2 \\
\hline \multirow{4}{*}{$M=7.3$} & 4 & 再現波1002 & 646.8 & 265.1 \\
\hline & 5 & 再現波1796 & 568.0 & 241.7 \\
\hline & 6 & 再現波1996 & 495.2 & 210.1 \\
\hline & 7 & 再現波2150 & 643.9 & 358.5 \\
\hline \multirow{2}{*}{ 鳥取県西部地震 } & 8 & TTR007 & 725.9 & 573.2 \\
\hline & 9 & TTR008 & 314.3 & 383.7 \\
\hline \multirow{2}{*}{$M=7.3$} & 10 & TTR009 & 628.2 & 595.5 \\
\hline & 11 & TTRH02 & 917.8 & 760.7 \\
\hline \multirow{4}{*}{ 宮城県北部の地震 } & 12 & MYG004 & 318.9 & 349.4 \\
\hline & 13 & M_WAKUYA & 555.2 & 513.2 \\
\hline & 14 & M_ISHINOMAKI & 390.4 & 488.7 \\
\hline & 15 & M_KAJIMADAI & 1605.5 & 910.3 \\
\hline
\end{tabular}

（＊再現波とは文献 38)の松島・川瀬らによる再現波）
表 6 各入力地震動に対する 1 層最大層間変位 $(\mathrm{cm})$

\begin{tabular}{|c|c|c|c|c|c|c|c|c|c|}
\hline No. & $\mathrm{Ta}$ & $\mathrm{IR}$ & $\mathrm{Ho}$ & $\mathrm{Ma}$ & $\mathrm{Sa}$ & $\mathrm{Ko}$ & $\mathrm{I}$ & $\mathrm{IS}$ & $\mathrm{Ka}$ \\
\hline 1 & 3.40 & 5.15 & 5.08 & 4.80 & 6.34 & 3.37 & 4.45 & 3.91 & 5.21 \\
\hline 2 & 3.23 & 5.54 & 5.27 & 3.58 & 7.52 & 2.94 & 5.97 & 4.88 & 4.48 \\
\hline 3 & 1.20 & 2.56 & 2.19 & 1.89 & 2.83 & 1.09 & 1.77 & 1.62 & 1.85 \\
\hline 4 & 1.97 & 4.18 & 3.67 & 2.20 & 4.50 & 1.59 & 3.54 & 2.82 & 2.56 \\
\hline 5 & 1.29 & 2.85 & 2.30 & 1.69 & 3.04 & 0.99 & 2.65 & 2.53 & 1.60 \\
\hline 6 & 0.75 & 1.85 & 1.37 & 1.91 & 1.19 & 0.66 & 2.28 & 2.22 & 1.44 \\
\hline 7 & 3.02 & 5.47 & 4.44 & 2.98 & 5.63 & 2.29 & 4.82 & 3.86 & 3.37 \\
\hline 8 & 2.21 & 3.65 & 3.07 & 2.64 & 4.23 & 2.18 & 3.27 & 2.75 & 2.32 \\
\hline 9 & 1.21 & 2.62 & 3.33 & 6.39 & 2.26 & 2.50 & 1.90 & 4.67 & 5.98 \\
\hline 10 & 1.37 & 2.02 & 3.34 & 1.99 & 2.58 & 2.11 & 1.74 & 1.50 & 1.94 \\
\hline 11 & 4.13 & 5.78 & 6.70 & 7.06 & 8.69 & 4.41 & 8.48 & 7.31 & 7.17 \\
\hline 12 & 0.73 & 2.01 & 1.28 & 0.73 & 0.94 & 0.81 & 2.14 & 1.09 & 3.21 \\
\hline 13 & 1.71 & 2.78 & 2.09 & 2.56 & 2.69 & 2.30 & 1.97 & 1.84 & 2.44 \\
\hline 14 & 0.90 & 0.70 & 0.45 & 0.83 & 0.64 & 0.69 & 0.69 & 0.51 & 0.68 \\
\hline 15 & 2.53 & 4.09 & 3.12 & 4.93 & 4.44 & 3.68 & 3.16 & 3.63 & 6.79 \\
\hline
\end{tabular}

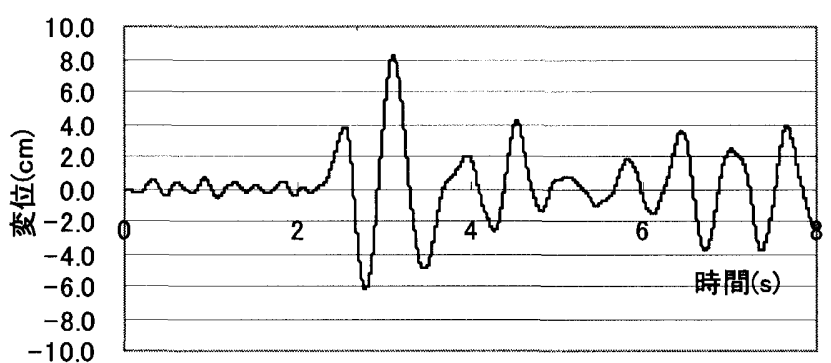

図 $13 \mathrm{Sa}$ 邸 TTRH02 波人力時の 1 層最大変位点時刻歷 (梁間方向)

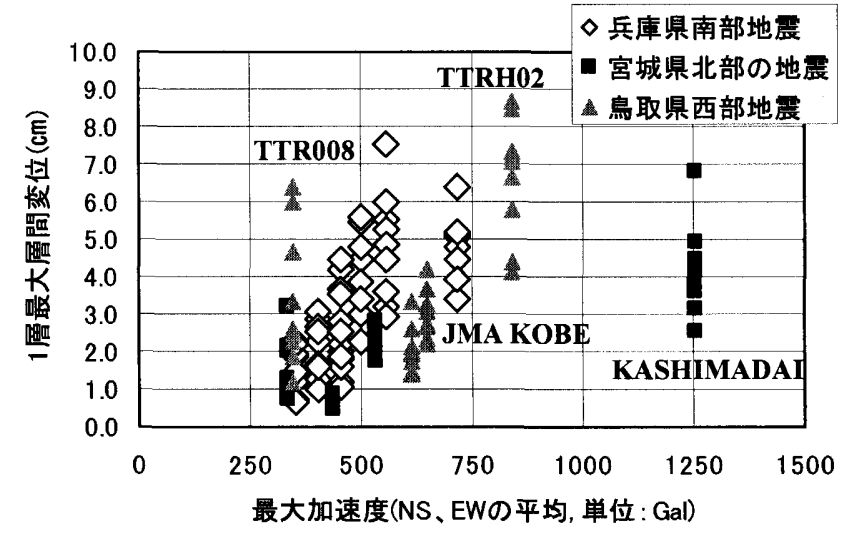

図 14 地震別の最大応答変位の比較

\section{参考文献}

1）静岡県：東海地震についての県民意識調查、静岡県

2）小野塚浩基、原田直希、大橋好光、坂本功：常時微動測定による軸組木 造住宅の振動特性に関する研究 (その 2)、日本建築学会大会学術講演梗概 集、構造 C- I 分冊、pp129〜130、1999.9

3）矢澤一樹、毛呂真：青森県の在来木造住宅の固有周期、日本建築学会大 会学術講演梗概集、構造 C- I 分冊、pp423 424、2002.8

4）川口陽子、岩田真次、藤田香織、坂本功、中園真人：民家の構造耐力性 能に関する実験的研究その 5、日本建築学会中国支部研究報告集、pp. 137 $\sim 140,2002.3$

5）山本浩之、林勝朗、西川忠：木造住宅の振動特性に関する研究(常時微動 計測による固有周期)、日本建築学会大会学術講演梗概集、構造 $\mathrm{C}$ 分冊、 pp. 131 132、1992.8

6）鈴木祥之、中治弘行、平山貴之、秋山真一：常時微動計測による木造住 宅の振動特性、日本建築学会大会学術講演梗概集、構造 C- I 分冊、pp. 221 
〜22, 1998.9

7）日本建築学会: 木質構造設計規準・同解説、日本建築学会、pp. 77〜 78, 1995

8）日本住宅・木材技術センター：Zマーク表示金物 - 木造住宅用接合金物の 使い方、金物審查委員会監修、（財）日本住宅・木材技術センタ一木造住 宅用優良接合金物推進協議全

9）白須万宽、笹川明、五十田博、塩野入克征：筋かい壁の履歴特性把握の ための静的繰り返し実験、日本建築学会大会学術講演梗概集、構造 C-I 分冊、 pp. 43〜 44、1997.9

10) 平坂継臣、木下加奈子：木造仕口部の魝性と耐力に関する実験的研究一 ほぞの耐力評価 (1) 一、日本建築学会大会学術講演梗概集、構造 C- I 分冊、 pp. 33〜34、1999. 9

15）稲山正弘、高津角行：木材のめりこみに関する実験的研究 その 1 : べ イマツ材の均等変位部分圧縮試験、日本建築学会大会学術講演梗概集、 構造 $\mathrm{C}$ 分冊、pp. $17 \sim 18 、 1991.9$

16）高津角行、稲山正弘：木材のめりこみに関する実験的研究 その $2:$ ス ギ材の均等変位部分圧縮試験、日本建築学会大会学術講演梗概集、構造 C 分冊、pp. 19〜20、1991.9

17）稲山正弘：木材のめりこみに関する実験的研究 その $3:$ 縁端距離、材 厚、加压面寸法が E1、E2、 0 y に及ほす影響の一般的傾向、日本建築学 会大会学術講演梗概集、構造 C 分冊、pp. 13〜14、1992.8

18）平嶋義彦、金谷紀行、畑山義男、神谷文夫：筋違入り軸組の剪断性能と その構造解析 (第 2 報) 軸組の構造解析、木材学会誌、Vol.27. No. 12、pp. 855 $\sim 862 、 1991$

19）飯塚五郎藏、高橋吉代志：木造仕口の剛節度試呀 (2) 現代構法、日本建築 学会大会学術講演梗概集、構造 C 分冊、pp. 1295 1296、1985.10

20）鎌田輝男、新谷隆：二ッ割筋違い入り木造軸組の耐力特性について、日 本建築学会大会学術詇演梗概集、構造 C-1 分冊、pp. 297 298、2001.9

21）井上正文、後藤靖 : 筋違端部の接合方法が片筋違入り木造骨組の構造特 性に与える影響について、日本建築学会構造系論文集、pp. 89 94、1999.7

22）定方啓他 4 名：木造軸組壁の耐力変形形状と履歴特性について一正負交 番荷重下の木質系構造要素の変形エネルギー吸収性状に関する研究(そ の2)、日本建築学会東海支部研究報告集、pp. 157〜158、1986

23）塩野入克征、笹川明、五十田博、白須万宽：筋かい壁の履歴特性把握の ための静的繰り返し試験 (その 1 ：筋かい壁の実験)、日本建築学会大会 学術講演梗概集、構造 C-I 分冊、pp. 81 82、1997.9

24) 後藤正美、耐力壁の考え方(筋かい)、建築技術 pp 162 167, 1997

25）安達文男、大橋好光、坂本功：在来木造建物の非耐力壁の水平せん断実 験、日本建築学会大会学術詇演梗概集 (構造系)、pp. 2661 2662、1984. 10

26) 林勝朗、岡田浩次：シージングボードと石静ボード張りの木造在来構法 耐力壁のせん断実験、日本建築学会大会学術講演梗概集、pp. 1365～1366、 1987.10

27）杉本健一、三井信宏、神谷文夫、新居健二、照井清貴、大口仁：石亮ボ ードを張った非耐力壁の面内せん断性能、日本建築学会大会学術講演梗 概集、構造 C- I 分冊、pp. 111 112、1998.9

28）杉本健一、三井信宏、神谷文夫：各種面材を張った軸組構法の壁の面内 せん断性能、日本建築学会大会学術講演梗概集、構造 C- I 分冊、pp. 319 $\sim 320 、 2001.9$

29）下屋敷朋千、岡部実、宮村雅史、小国勝男、佐久間博文、大野吉昭：石 高ボード貼り在来軸組構法耐力壁の面内せん断耐力、日本建築学会大会 学術講演梗概集、構造 C- I 分冊、pp. 323 324、2001.9

30）坂本功、大橋好光：木造軸組ラスモルタル壁の水平せん断実験（その 1)、 日本建築学会大会学術講演梗概集、pp. 2077〜2078、1982.10

31）大橋好光、坂本功：木造軸組ラスモルタル壁の水平せん断実験 (その2)、 日本建築学会大会学術講演梗概集、pp. 2079 2080、1982.10

32）小野塚浩基、大橋好光、坂本功：常時微動測定による軸組構法木造住宅 の振動特性に関する研究、日本建築学会大会学術講演梗概集、構造 C-I 分冊、pp. 219〜220、1998.9

33）日本建築学会：建築耐震設計に招ける保有耐力と変形性能、日本建築学
会、 1990

34）後藤正美、鈴木有、浦憲親：一方向水平加力実験による実在木造建物の 耐震性能の検討、日本建築学会構造系論文集、第 506 号、pp.147 154、 1998.4

35）包那仁満都拉、川瀬博 : 常時微動計測に基づく中低層 RC 造建物の振動特 性とその耐震性評価、日本建築学会構造系論文集、pp.29～36、2004.3

36）日本住宅・木材技術センター：木造住宅実大振動実験報告書、(財)日本住 宅・木材技術センター、平成 8 年 10 月

37）棠澤健二、小原勝彦：木造軸組構法住宅の実大振動実験、工学院大学総 合研究所年報、平成 10 年 3 月

38) 松島信一、川瀨博：1995 年兵庫県南部地震の複数アスペリティモデルの 提案とそれによる強震動シミュレーション、日本建築学会構造系論文集、 第 534 号、PP. 33 40、2000.8

39）防災科学技術研究所：強震ネットワーク (http://www.k-net.bosai.go.jp)

40）防災科学技術研究所：基盤強震ネットワーク (http://www.kik-net.bosai go.jp/kik)

41) 気象庁: 95 型震度計波形データ (2003 年 7 月 26 日 宮城県北部の地震)、 (財)気象業務支援センター

42）木造住宅の耐霞精密搒断法と補強方法：日本建築防砂協会（発行）

付䟿

强震動シミュレーションの対象とした計 9 棟のうち、Ta 邸以外（本論中に 揭载）の 8 棟の構造モデルを示す。(この図はモデルのイメージを揌んで頂く ために揭載しており、建物の穛尺などに違いがあるので注意されたい)
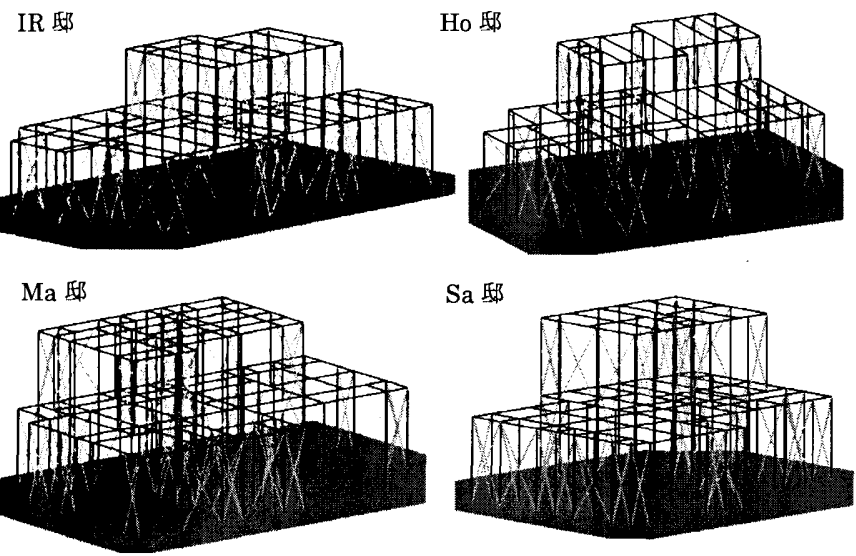

Ko 馎

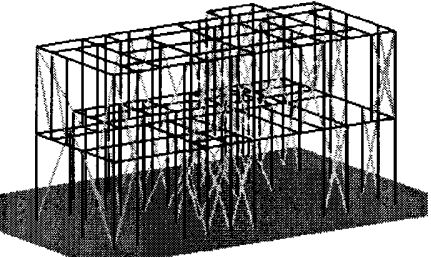

I 邸

IS 邸
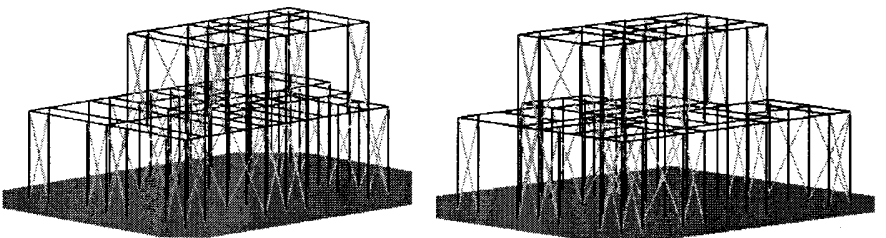

桁行方向

梁間方向

(2004年 3 月31日原稿受理，2005年 2 月18日採用決定） 